\title{
液体界面の構造, 分光, 輸送の理論研究 Theoretical Study of Structure, Spectroscopy, and Transport at Liquid Interfaces
}

\author{
石山達也
}

Tatsuya Ishiyama

\begin{abstract}
Liquid interfaces are ubiquitous and of fundamental importance in many physicochemical phenomena, such as atmospheric reactions on aerosol particles, cavitation bubbles, biochemical reactions, and so forth. The interfacial region is very limited in space and has unique properties compared to the bulk due to its heterogeneous environment. Molecular simulation is a powerful technique to elucidate and predict physical and chemical properties of interfaces with thickness of nm order. In this review, we focus on the recent progress of the simulation studies of molecular structure, vibrational spectroscopy, and transport phenomena at the interfacial region. A key experimental technique to elucidate interfacial molecular structure is the interface-selective vibrational sum frequency generation (VSFG) spectroscopy. A close collaboration of VSFG studies with molecular simulation has opened an avenue for understanding new aspects of the structures of aqueous surfaces. We discuss some important properties of water to interpret the interfacial vibrational spectra. We further review the recent development of the simulation studies for the transport phenomena associated with condensation and evaporation at liquid interfaces.
\end{abstract}

Keywords: molecular dynamics simulation, VSFG spectroscopy, water surface, condensation and evaporation

\section{1.はじめに}

液体界面は我々の身の回りにありふれている。例えば, 地球大気は海洋表面と接している。また，大気中には微小 だが数多くの海塩エアロゾル粒子が浮遊しており，それら の表面積の合計は地球表面積の 100 倍以上にもなるといわ れている。そのため, 大気化学の分野ではグローバルな大 気環境がエアロゾル表面に存在する分子と気相分子との不 均質反応によって大きく影響を受けると考えられている ${ }^{1}$ 。 このような不均質場での反応過程を理解するためには，工 アロゾル表面，つまり液体表面に活性な分子種，分子配向， 水素結合環境などの「構造」を理解する必要がある ${ }^{2} 。 ま$ た，液体界面での蒸発・凝縮をはじめとする物質・エネル ギーの「輸送」の速度を知ることも大気反応モデルを構築 する上で重要な課題となる ${ }^{3,4}$ 。

液体界面の構造をプローブする実験手段は非常に限られ る。例えば, 光電子分光法 5 などの実験では, 気相側を真 空にせねばならず，蒸発が生じる液体界面の構造を特定す るにはいくらか困難を伴う。また, 界面深さ方向の分解能 という観点からも，それらの方法で得られる情報にはあい まいさが伴う。一方，界面を選択的にプローブする手法と して発展してきた分光法として， 2 次の非線形光学過程を 利用した和周波発生 (Sum Frequency Generation, SFG) 分 光法 ${ }^{6}$ がある。この分光法では， 2 種類の入射電場を界面 に照射し，界面に生じる 2 次分極の影響により発生する
SFG 光をプローブする。この SFG 光は, 原理的に対称性が 破れた領域からのみシグナルを発生するため, バルクの気 相や液相領域では禁制，界面のような領域で許容となる。 また，入射する 2 つの光のうちの 1 つを赤外光で掃引する ことにより，それに共鳴した波数の分子振動を特定できる ため，界面敏感な振動和周波（Vibrational SFG, VSFG）分 光法として利用できる。さらに，水溶液系の問題に限って いえば，水の $\mathrm{OH}$ 振動が水素結合環境に敏感に応答しスぺ クトルシフトが起こるため, 界面での詳細な水素結合構造 が議論できる ${ }^{7-9}$ 。しかし，界面振動スペクトルもまた，そ の解釈にはしばしば曖昧さを伴う。これは，実験では界面 での複数の構造に起因するスペクトルの成分が全て重なっ た結果として全体の 1 つのスペクトルが観測され，そのス ペクトルを一意的に分解することが難しいからである 7 。 の問題に対してVSFG 分光法に対する「理論」による解析 が有効である ${ }^{10}$ 。近年我々は，分子シミュレーションによ り界面構造とともにVSFG スペクトルを第一原理的に計算 することにより，実験だけでは解釈が難しい問題に焦点を あててきた ${ }^{11}$ 。

ところで，エアロゾル粒子のように正の曲率をもった界 面の問題のほかに，気泡のように負の曲率をもった界面が 生じる問題もある。気泡が存在する液体に超音波を照射す ると, 圧力場の振動が気泡の固有振動数に一致するときに 気泡は大振幅で振動する ${ }^{12}$ 。この現象により気泡内の気体 
は急激に圧縮され，キャビテーションとよばれる気泡の崩 壊現象が生じる ${ }^{13}$ 。気泡崩壊時には気泡内の環境は超高 温・高圧状態となり, 古くから船舶などのプロペラの損傷 などの問題となっていた。最近では, 微小気泡を体内に注 入し，患部に超音波を照射することにより結石破壊やド ラッグデリバリーなどの医療に応用しようとする研究も行 われている。このようなキャビテーション気泡の特性を理 解する上で重要となるのが, 界面での物質・エネルギー輸 送のモデル化である ${ }^{14}$ 。気泡振動の問題は, 液相, 気相 (バルク領域) に対して流体力学（連続体理論）, 界面の振 動ダイナミックスには連続体理論から導かれる RayleighPlesset 方程式を用いることにより定式化できる ${ }^{14}$ 。しかし ここで問題となるのは, Rayleigh-Plesset 方程式の質量輸送 の項に凝縮係数 $\alpha_{c}$, 蒸発係数 $\alpha_{e}$ なるパラメータが含まれ ることである。これらのパラメータは連続体理論の枠組み だけで決めることができず，界面での蒸発・凝縮に起因す る物質・エネルギーの分子レベルでの「輸送」と関係して いる ${ }^{14}$ 。これまで，これらのパラメータを実験的に測定す る試みがなされてきたが, パラメー夕決定に用いられる理 論にいくつかの仮定が導入されることや， $\alpha_{c}$ や $\alpha_{e}$ の值が 界面での不純物により非常に敏感に変化するなどの理由に より，報告される值には 3 桁ものばらつきがあった ${ }^{15} 。 こ$ の問題に対しても,「理論」による手法が有効となる。本研 究は, $\alpha_{c}$ や $\alpha_{e}$ の值を分子シミュレーションで直接計算す るとともに，これまで実験によるパラメータ決定に用いら れてきた理論の妥当性を検証してきた ${ }^{16}$ 。

上に述べたように，本研究はこれまで液体界面の「構造」， 「分光」,「輸送」をキーワードとし，それらに対して「理 論」によるアプローチを行ってきた。手法としては, 電子 状態計算に基づく分子モデリング, さらには分子動力学 (Molecular Dynamics, MD) シミュレーションである。本解 説では，上述の液体界面研究に対し，理論研究がどのよう に貢献してきたかについて我々の成果を中心に概説する。

\section{2. 液体界面の「構造」「分光」の理論的アプローチ}

液体界面の振動分光計算, あるいは構造計算で重要とな るのは，「電子分極」の効果をどのようにモデル化するかと いう点にある。以下，主に水界面を例にこの点を説明する。

まず，SFGスペクトルの計算方法の概要からはじめる。2 つの入射電場 $\boldsymbol{E}_{1}, \boldsymbol{E}_{2}$ (Figure 1b) により生じる界面 2 次分 極 $\boldsymbol{P}$ は,

$$
\boldsymbol{P}=\chi \boldsymbol{E}_{1}, \boldsymbol{E}_{2}
$$

と表される。ここで， $\chi$ は 2 次の非線形感受率であり，振 動共鳴部分 $\chi^{R}$, 非共鳴部分 $\chi^{N R}$ の和として

$$
\chi=\chi^{R}+\chi^{N R}
$$

と表される。通常, VSFG スペクトルIは，いわゆるホモ
ダイン検出とよばれる方法 ${ }^{17}$ で $I \sim|\chi|^{2}$ を測定する。しか し，この方法だと $\chi$ の位相情報が消失してしまうため, 最 近の実験研究の発展により $\chi$ そのものを測定するへテロダ イン検出 VSFG（Heterodyne-Detected VSFG, HD-VSFG）法 が開発された。このあたりの詳細は, 理化学研究所, 二本 柳氏（第 5 回分子科学会奨励賞受賞）の解説 ${ }^{18}$ が詳しい。2 つの入射電場のうちの 1 つを可視光（vis）として振動数を 固定，もう 1 つの光を赤外光（IR）で掃引し (Figure 1b), 界面に存在する測定対象分子の分子振動と共鳴させること により HD-VSFG スペクトルとして有意な $\chi^{R}$ スペクトルが 得られる。ここで, MD シミュレーションで $\chi^{R}$ をどのよう に計算するのかという問題になるが，実験と同様にシミュ レーション中で外場 $\boldsymbol{E}_{1}, \boldsymbol{E}_{2}$ を照射させる，いわゆる非平衡 (Non-Equilibrium, NE) MD シミュレーションを行うことが 直感的には理解しやすい。しかし, NEMDでは一般に実験 条件よりも大きく平衡状態からずらさなければ応答関数が 評価しにくいことや，シミュレーション自体が複雑になる ことなどの欠点がある。そこで，線形応答理論に立脚した 平衡 $\mathrm{MD}$ シミュレーションにより応答関数 $\chi^{R}$ を評価する 方法が用いられる。この方法では， $\chi^{R}$ が以下に示すように 系の双極子モーメント $\boldsymbol{M}$ と系の分極率 $\boldsymbol{A}$ の時間相関関数 のフーリエ・ラプラス変換により計算される ${ }^{19}$ 。

$$
\chi_{p q r}^{R}=\frac{i \omega_{\mathrm{IR}}}{k_{B} T} \int_{0}^{\infty} d t \exp \left(i \omega_{\mathrm{IR}} t\right)\left\langle A_{p q}(t) M_{r}(0)\right\rangle
$$

ここで, $\omega_{\mathrm{IR}}$ は振動数 (赤外領域), $k_{B}$ は Boltzmann 定数, $T$ は温度, $t$ は時間であり, $p q r \sim x, y, z$ であ。 $\mathrm{MD}$ シミュ レーションでは Figure 1a に示すように液膜を形成させて界 面を作り， $z$ を界面垂直方向， $x, y$ を界面平行方向にとるの が一般的である ${ }^{19}(z$ を液相から気相へ向かう方向にとり なおすことにより 2 つの界面に対するアンサンブル平均が とれる)。また， $\boldsymbol{M}$ と $\boldsymbol{A}$ は，それぞれ分子 $i$ の双極子モー

(a)

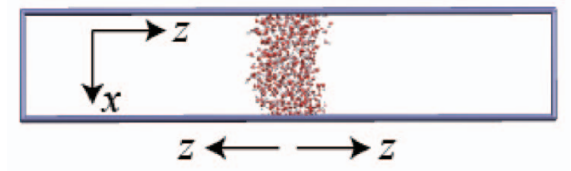

(b)

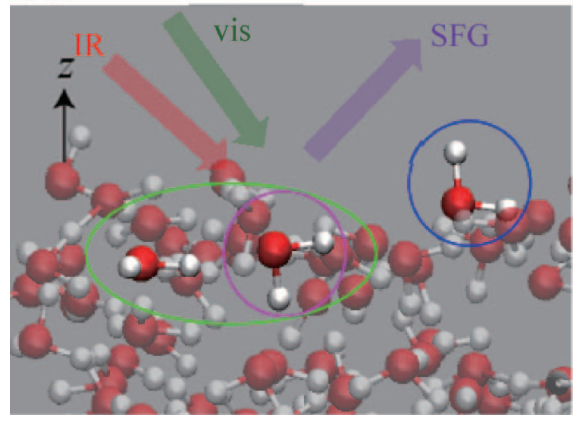

Figure 1. (a) MD simulation system of a slab geometry. (b) A snapshot at an air/water interface. Blue circle represents a free $\mathrm{OH}$ moiety, purple an $\mathrm{H}$-bonding one, and green a strong $\mathrm{H}$-bonding complex. 
メント $\mu_{i}$ と分極率 $\alpha_{i}$ の和として表される。

$$
\boldsymbol{A}(t)=\sum_{i}^{\text {molecules }} \boldsymbol{\alpha}_{i}(t), \quad \boldsymbol{M}(t)=\sum_{i}^{\text {molecules }} \boldsymbol{\mu}_{i}(t)
$$

MD シミュレーションでは分子のダイナミックスを計算す るので，分子の分極率や双極子モーメントの分子振動に対 する摇らぎの時間発展が計算できれば上式から $\chi^{R}$ が計算で きることになる。

ところで，水分子の双極子モーメントは，気相中で 1.85 $\mathrm{D}$ ，液相中で $3.0 \mathrm{D}$ 程度の值をとることが知られている 20 。 これは, 液相中では水分子が周囲分子からの電場を感じて 分極するためである ${ }^{21}$ 。一般に, 分子 $i$ の双極子モーメン 卜 $\boldsymbol{\mu}_{i}$ は, 分極率 $\boldsymbol{\alpha}_{\boldsymbol{i}}$ と分子にかかる電場 $\boldsymbol{E}_{i}$ (外場 $\boldsymbol{E}_{i}^{0}$ と区別 してここでは $\boldsymbol{E}_{i}$ を局所場とよぶ）と

$$
\boldsymbol{\mu}_{i}=\boldsymbol{\mu}_{i}^{0}+\alpha \boldsymbol{E}_{i}
$$

の関係にある。ここで, $\mu_{i}^{0}$ は気相中での双極子モーメント であり, 液相中の分子は $\alpha_{i} E_{i}$ の大きさの誘起双極子モーメ ントをもつことになる。局所場 $\boldsymbol{E}_{\boldsymbol{i}}$ は, 外部電場 $\boldsymbol{E}_{\boldsymbol{i}}^{0}$ のほか に，周囲分子からの双極子場の項が加わる。

$$
\boldsymbol{E}_{i}=\boldsymbol{E}_{i}^{0}-\boldsymbol{T}_{i j} \boldsymbol{\mu}_{j}
$$

ここで， $\boldsymbol{T}$ は dipole tensor とよばれるもので, 周囲の双極 子モーメント $\boldsymbol{\mu}$ と局所場を関係付ける ${ }^{21}$ (式(5)はいわゆる Lorentz の局所場である)。式 (4) (5) はそれぞれ $3 N(N$ は分 子数）個の連立方程式となっており, $\boldsymbol{\mu}^{0}, \boldsymbol{\alpha}, \boldsymbol{E}^{0}$ が与えられ たときの分子の双極子モーメント $\boldsymbol{\mu}$ を与える。通常，MD シミュレーションでは，式(4)(5)を Self-Consistent Field （SCF）計算するため ${ }^{22}$, 計算のボトルネックとなる部分の ひとつとなる。

局所場効果 ${ }^{19}$ を力場計算や式(3)の VSFG スペクトル計 算に取り入れることは，界面シミュレーションにおいて重 要となる問題が多い。例として，以下では空気／水界面, あるいは空気／氷界面での実験と計算によるVSFG スペク トルを議論する。なお， $\chi^{R}$ は位相情報をもつため, 実験や 計算では実部と虚部のスペクトルが得られる（実部と虚部 は Kramers-Kronig の関係 23 があるため互いに独立ではない)。 一般に，実部は分散型，虚部は吸収型のバンド形を示すが， 通常は虚部スペクトルが注目される。これは, 虚部スペク トルの符号が界面での分子の方向を反映すると考えられる からである ${ }^{18}$ 。例えば, 空気 / 水界面の場合, $\operatorname{Im}\left[\chi_{x x z}^{R}\right]$ が 正のバンドを示せば，界面で $\mathrm{OH}$ が上側（液相から気相側） を向いていること，負のバンドを示せば $\mathrm{OH}$ が下側を向い ていると解釈される。少し詳しく説明すると $\operatorname{Im}\left[\chi^{R}\right]$, が遷 移分極率と遷移双極子モーメントの積に比例するという関 係

$$
\operatorname{Im}\left[\chi_{x x z}^{R}\right] \sim\left(\partial \alpha_{x x} / \partial Q\right)\left(\partial \mu_{z} / \partial Q\right)
$$

$(Q$ は振動座標）がある。ここで，1つの OH に着目し $Q$ を
$\mathrm{OH}$ 長とした場合， $\mathrm{OH}$ が伸びるとき $(\partial \alpha / \partial Q)>0$ となり，

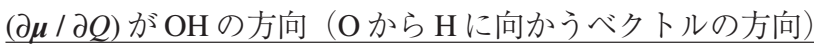
にほぼ一致するためである ${ }^{11}$ 。この下線部の仮定は，気相 中では十分よく成り立つと考えられるが，界面のような不 均質な環境で，特に強く水素結合した水で成り立つかどう かは前述の局所場の性質から考えると自明ではない。実際, 水が強く水素結合する場合に $\operatorname{Im}\left[\chi^{R}\right]$ スペクトルを解釈する 上でこの仮定が破綻することが以下で示される。

Figure 2 に空気／水界面に対する MD シミュレーション で計算された $\operatorname{Im}\left[\chi^{R}\right]$ スペクトルを示す。赤色の線は局所場 効果を考慮していない結果，青色の線はそれを考慮した結 果を表している。どちらの結果も， $3,700 \mathrm{~cm}^{-1}$ において正 のバンド, $3,600 \mathrm{~cm}^{-1}$ 以下の領域において負のバンドを示 している。前者は水表面で気相側に突き出した $\mathrm{OH}$ （Free $\mathrm{OH}$, Figure $1 \mathrm{~b}$ の青丸の構造）に，後者は水素結合した $\mathrm{OH}$ (H-bonding OH, Figure 1bの紫丸の構造）に起因したバンド である。Figure 2 において, Free $\mathrm{OH} の 3,700 \mathrm{~cm}^{-1}$ における バンドは局所場効果が小さいため 2 つの線の差が小さく, H-bonding $\mathrm{OH}$ のバンドは水素結合による局所場効果が大き いためそれらの差が大きくなることがわかる。Figure 2 の 左上に示された実験による $\operatorname{Im}\left[\chi^{R}\right]$ スペクトル 24 と比較する と，実験結果は局所場効果を考慮したものに近い。

これらのことから，局所場効果をスペクトル計算に取り 入れることは「定量的」な意味で重要であることがわかる。 さらに，これが「定性的」な意味で重要となる問題がある。 Figure $3 \mathrm{a}$ に2 008 年に実験ではじめて報告された空気／水 界面の $\chi^{R}$ スペクトル 25 を示す。Figure 2 と比較してもっと も特徵的なのは, 赤色の $\operatorname{Im}\left[\chi^{R}\right]$ スペクトルにおいて 3,200 $\mathrm{cm}^{-1}$ 以下の低波数領域で正のバンドが新たにみられること である。これは, 比較的強い水素結合領域で遷移双極子 モーメントが正を示す構造が存在することを意味している。 このバンドに対する初期の帰属では, 先に述べた下線の仮 定に基づき，水界面において気相側に向いた $\mathrm{OH}$ が強く水 素結合した結果によるものとされた ${ }^{25}$ 。しかし，MDシミュ レーションでは上を向けた $\mathrm{OH}$ が平均的に強く水素結合す

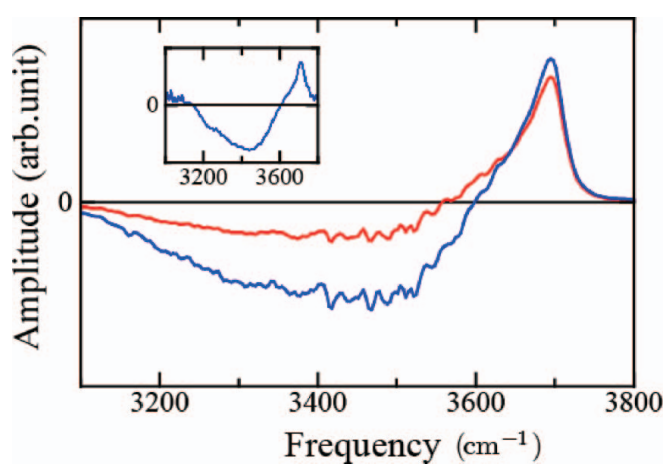

Figure 2. MD simulation results of $\operatorname{Im}\left[\chi_{x x z}\right]$ spectrum of water surface at $300 \mathrm{~K}$. Red line denotes the spectrum without taking the local field effect into account, and blue line the spectrum with it. Inset is the experimental spectrum ${ }^{24}$. 
るような構造は見出されない。先に結論からいうと，水が 強く水素結合した場合には $\mathrm{OH}$ の振動に伴う分子間の電荷 移動効果が無視できなくなり, $\mathrm{OH}$ の方向と遷移双極子モー メントの方向が大きくずれることが, 低波数側で正のバン ドを示す主な原因であることが我々の研究から明らかと なった ${ }^{26-28}$ 。この効果は, 界面における溶媒環境に起因し た孤立分子描像からのずれという意味では，局所場効果の
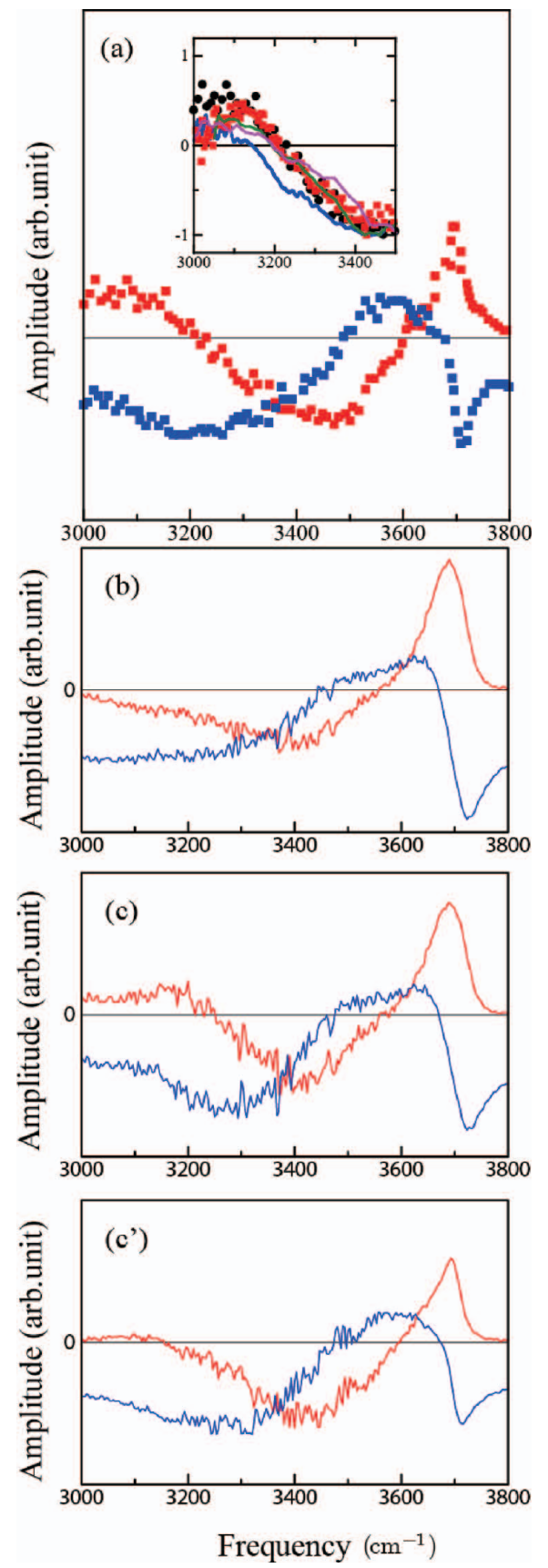

Figure 3. $\chi_{x x z}$ spectrum of water surface at $300 \mathrm{~K}$. Blue and red symbols denote real and imaginary parts, respectively. (a) Experimental result ${ }^{25}$. The inset shows the experimental $\operatorname{Im}\left[\chi_{x x z}\right]$ reported by several groups. Black circles : ref. 25 , blue line : ref. 24 , red squares : ref. 30 , green line : ref. 31, pink line : ref. 32. Each data is normalized by the minimum value of $\operatorname{Im}\left[\chi_{x x z}\right]$. (b) MD simulation results with taking account of polarization only. (c) MD simulation results with taking account of polarization and charge transfer effects by the point-dipole polarizable model ${ }^{27}$. (c') MD results by the charge response kernel polarizable model ${ }^{27}$. This figure is reproduced from ref. 27.
ひとつであるといえる。実際，MD シミュレーションにお いて, 電荷移動の効果を取り込まない場合（Figure 3b）と 実効的に取り込んだ場合（Figure 3c）とを比較すると, 定 性的にスペクトルが変化し, 後者のスペクトルが実験に近 づくことがわかる。では，具体的にこの低波数側のスペク トル成分は界面のどのような構造に起因して発生するのた ろうか。

界面のような不均質環境では，バルクと比較すると分子 間に働く力の均衡が平均的に破れており，表面張力など界 面特有の現象を引き起こす。表面張力は, 界面垂直方向と 界面平行方向の圧力差により定義される ${ }^{29}$ 。ビリアル定理 から界面平行方向の相互作用が垂直方向よりも大きくなる 結果として正の表面張力が生じることからも，一般に界面 平行方向の相互作用は垂直方向よりも大きいといえる。表 面張力は一般に界面平行方向の結合の “数” が垂直方向よ りも多いことで理解されるが，水の場合には界面での“結 合の強さ”にも影響があらわれることが以下の解析により 示される。Figure 4 に, Figure 1aで示された水の液膜に対 して界面平行方向と垂直方向に分解した赤外吸収スペクト ルの差スペクトルの計算結果を示す。ここで，赤外吸収ス ペクトルの時間相関関数表示

$$
I^{\mathrm{IR}}(\omega)=\frac{1}{2 \pi} \int_{-\infty}^{\infty} d t e^{-i \omega t}\langle\boldsymbol{M}(0) \cdot \boldsymbol{M}(t)\rangle
$$

に対して，界面平行方向成分

$$
I_{\|}^{\mathrm{IR}}(\omega)=\frac{1}{2 \pi} \int_{-\infty}^{\infty} d t e^{-i \omega t}\left\langle\left(M_{x}(0) M_{x}(t)\right\rangle\right.
$$

と垂直方向成分

$$
I_{\perp}^{\mathrm{IR}}(\omega)=\frac{1}{2 \pi} \int_{-\infty}^{\infty} d t e^{-i \omega t}\left\langle\left(M_{z}(0) M_{z}(t)\right\rangle\right.
$$

を定義し $\left(I^{\mathrm{IR}}=2 I_{\|}^{\mathrm{IR}}+I_{\perp}^{\mathrm{IR}}\right)$, それぞれを Figure $4 \mathrm{a}$ の青と赤 の線で示した。また，それらの差スペクトル

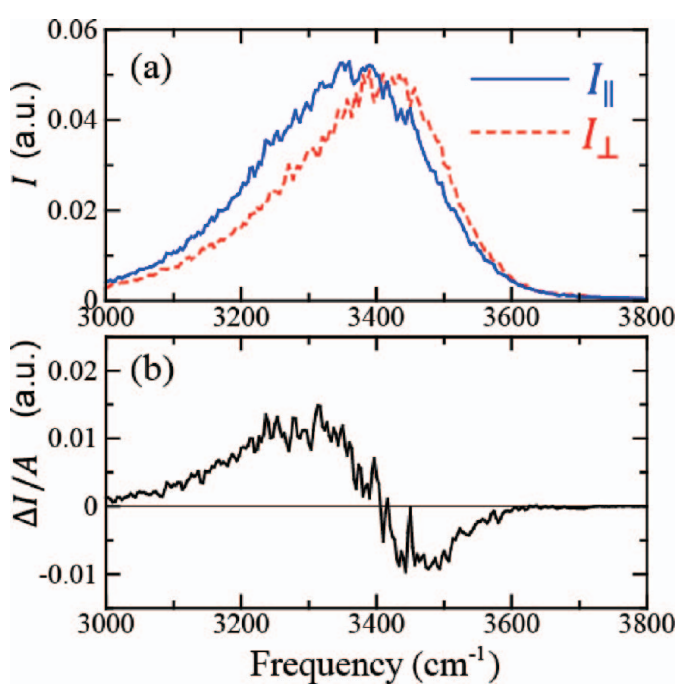

Figure 4. IR line-shape functions for liquid slab of water. (a) Normal (blue) and tangential (red) components of $I^{\mathrm{IR}}$. (b) The difference spectrum divided by the surface area $\Delta I / A$. This figure is reproduced from ref. 28. 


$$
\Delta I=I_{\|}^{\mathrm{IR}}(\omega)-I_{\perp}^{\mathrm{IR}}(\omega)
$$

を Figure $4 \mathrm{~b}$ に示した。ここで，等方的バルク領域において は $\Delta I=0$ となるが, 界面では不均質な相互作用のために $\Delta I \neq 0$ となる。Figure 4a をみると, 界面の不均質性のため に $I_{\|}^{\mathrm{IR}}$ と $I_{\perp}^{\mathrm{IR}}$ が若干ずれていることがわかる。さらにそれ らの差スペクトル（Figure 4b）からは，水素結合が強い低 波数側では $I_{\|}^{\mathrm{IR}}$ の成分が, 比較的水素結合が弱い高波数領 域で $I_{\perp}^{\mathrm{IR}}$ の成分が大きいことがわかる。これは, 界面平行 方向の水素結合が垂直方向より強いことを示す結果である。 ところで，界面平行方向の $\mathrm{OH}$ の振動成分が界面垂直方向 の遷移双極子成分をどのように生成するのだろうか。我々 の $\mathrm{MD}$ シミュレーション 27 にると, 空気/水界面では Figure 5 に示すような水素結合の 2 量体構造が多く存在す ることがわかった（例えば Figure 1b の緑丸で示された構 造)。強く水素結合したドナー $\mathrm{OH}$ が界面平行方向に振動す ると, アクセプターとの水素結合 2 量体内において電荷移 動が起こり，界面垂直方向の双極子を誘起する。これは， 先に下線で示した仮定, つまり $\mathrm{OH}$ の方向と遷移双極子の 方向が一致するという孤立分子描像が崩れる典型的な例で あり, 界面分光を理解する上で電子分極効果, 局所場効果 の重要性を示した結果であるといえる。

ここで 1 つ特記事項を加えておく。2008 年以降, 空気 $/$ 水界面の $\chi^{R}$ スペクトルが位相敏感測定により異なる実験グ ループにより報告されてきたが24,25,30-32, Figure 3aに示さ れる低波数ピークの大きさは実験間で異なっているように 思われる (Figure 3a の扦入図)。我々の理論計算において も, Figure $3 \mathrm{c}$ で示した低波数ピークの大きさは, 別の分極 モデルで計算すると Figure 3c'のように小さくなる。理論 計算では, 低波数成分は水の配向効果に起因する負のシグ ナルと分極＋電荷移動による正のシグナルの打ち消しあい の結果生じているため, 低波数成分の大きさは用いる分極 モデルに依存する。低波数ピークの大きさの問題は, 今後, 実験－理論間で検討していくべき問題のひとつであろう。

我々はさらに空気／氷界面でも同様の MD シミュレー ションを行い ${ }^{33,34}$, 上述の効果が実験によるスペクトルを 再現する上で重要であること示した。Figure 6 に実験によ

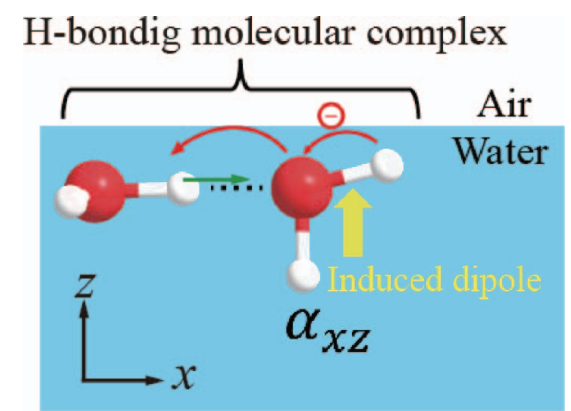

Figure 5. H-bonding water pair at the vapor/water interface. The $\mathrm{OH}$ stretching (green arrow) induces the anisotropic dipole (yellow arrow ${ }^{27}$.
り得られた空気/水界面に対する $|\chi|^{2}$ スペクトル 35,36 を示 す（実験による $\chi$ スペクトルの報告例はまだない）。空気／ 水界面に対するスペクトル（Figure 6の右上の図）と比較

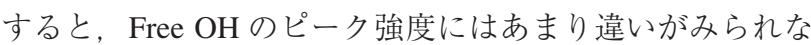
いが，水素結合領域の強度が非常に強くなることがわかる。 氷になるとなぜここまでピーク強度が増大するかは実験だ けでは明らかにはならなかった。しかし, 以下の理論解析 により，このピークを計算で再現するためは，局所場効果， 特に電荷移動による効果を考慮することが重要であること を明らかにした ${ }^{33}$ 。水分子間の電荷移動量は, 水素結合構 造の複雑な関数で表されると考えられ，それをモデル化し 古典 MD 計算にフルに取り込むことは特に氷のような問題 では難しい。ここでは式(3)の $\boldsymbol{M}$ と $\boldsymbol{A}$ を，注目する一部の 水に対して電子状態計算で直接解く方法 $\left(\mathrm{QM} / \mathrm{MM}\right.$ 計算 $\left.{ }^{37}\right)$ を導入しスペクトル解析を行った。Figure 7 に, QM/MM 計 算で得られた空気／氷界面での $|\chi|^{2}$ スペクトルの結果を示 す。赤線は局所場効果 (分子内電荷移動, 分子間電荷移動) を考慮していない結果，緑線は分極効果（分子内電荷移動） のみ考慮した結果, 青線は局所場効果を考慮した結果を表 す。局所場効果を取り入れていない結果は水素結合領域に おいてほとんどスペクトル強度を示さないが，分極効果を

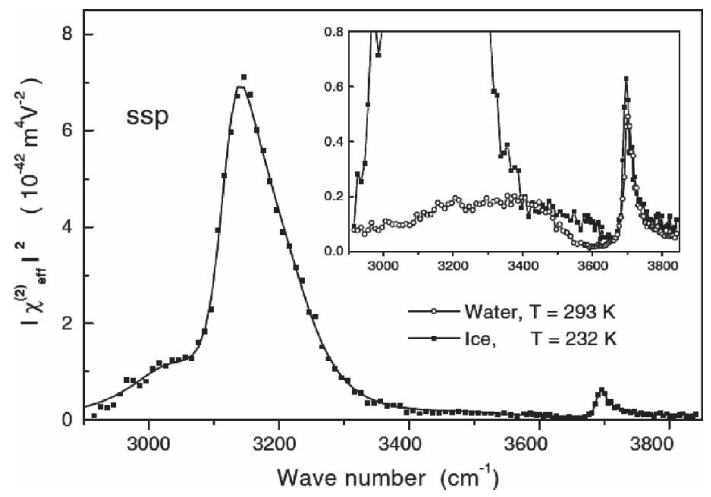

Figure 6. Experimental $|\chi|^{2}$ spectrum of air/ice interface (rectangular symbols). The inset shows that of air/water interface (circles). This figure is reproduced from ref. 33 .

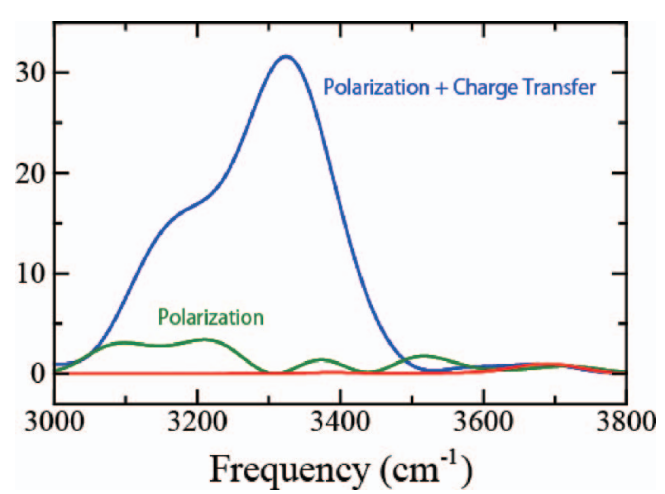

Figure 7. Calculated $|\chi|^{2}$ spectrum of air/ice interface at $230 \mathrm{~K}$. Red is the result without the local field effect (polarization + charge transfer), green with polarization effect only, and blue with the local field effect. This figure is reproduced from ref. 33 . 
取り入れると Free $\mathrm{OH}$ のピークと同程度の強度を与える。 さらに，分子間の電荷移動効果を取り入れると，氷表面特 有の非常に強いスペクトルが再現されることがわかる。さ らに, 水表面は水表面と比較して $\mathrm{OH}$ 振動がかなり非局在 化していることがわかった。 $\mathrm{OH}$ が協調的に振動すると, 分 子間電荷移動による遷移双極子モーメントが非常に大きく なるために，氷表面では水素結合領域においてスペクトル 応答が強くなると考えられる。また, 電荷移動の効果がほ とんど効かない Free $\mathrm{OH}$ 領域のスペクトル強度が，水表面 と同程度であることも納得できる。

ここまでは, 水あるいは氷表面の VSFG スペクトル応答 を解釈する上で, 局所場効果が重要な役割を果たしている ことをみてきた。上記の VSFG スペクトルは時々刻々変化 する $\mathrm{OH}$ 振動に対する応答が平均化されているものである が，これを時間軸方向に分解する時間分解 VSFG スペクト ルの研究 31,38-43も行われるようになってきた。これまで議 論したスペクトルを, 時間分解スペクトルと区別して定常 状態スペクトルとよぶことにすると, 例えば振動緩和の時 間スケールは, 定常状態スペクトルのピーク幅からある程 度議論できる。しかし, 周囲の水素結合環境の変化に伴い 振動数が変化する現象（スペクトル拡散）や, Free OH で あった振動子がある時間経過後に H-bonding $\mathrm{OH}$ に水素結 合を組みかえるといった現象 (chemical exchange ${ }^{44}$ ) など のダイナミクスを議論する上では, 時間分解スペクトル解 析は大変有用である ${ }^{45}$ 。時間分解の方法では, 基底状態に ある $\mathrm{OH}$ 振動を振動数 $\omega_{\text {pump }}$ のポンプ光により励起（ $v=$ $0 \rightarrow 1)$ させ，ある $\tau_{2}$ の遅延時間後に振動数 $\omega_{\text {probe }}$ のプロー ブ光による $v=0 \rightarrow 1$ の吸収と $v=1 \rightarrow 0$ の誘導放出, あ るいは $v=1 \rightarrow 2$ の励起吸収バンドを観測する。ポンプ過 程により $v=0$ の基底状態占有数が減少し, 励起状態 $(v=$ 1）の占有数が増加するので, プローブ過程における $v=$ $0 \rightarrow 1$ の吸収バンド（ブリーチバンド）は減少し, 逆にv= $1 \rightarrow 2$ の吸収バンド（ホットバンド）は増加する。振動子 が非調和的であれば, $v=0 \rightarrow 1$ の振動数より $v=1 \rightarrow 2$ の 振動数の方が小さくなるので, 時間分解スペクトルには

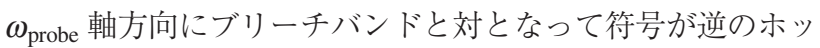
トバンドがあらわれる。Figure 8aに，2013 年にはじめて実 験で報告された空気/水界面での時間分解 2 次元 (2D) HD-VSFG スペクトル 46, Figure 8（b）に我々の MD 計算 により得られた $2 \mathrm{D}$ HD-VSFG スペクトル 47 を示す。ここ で, 横軸に $\omega_{1}=\omega_{\text {pump }}$, 縦軸に $\omega_{3}=\omega_{\text {probe }}$ をとった Figure 8 の $2 \mathrm{D}$ スペクトルは, ポンプとプローブ過程の遅延時間 $\tau_{2}$ がほぼ 0 psのものである。一般に $2 \mathrm{D}$ スペクトルは $\tau_{2}$ の発 展とともにスペクトルが変化していくことにより界面での $\mathrm{OH}$ 振動のダイナミクスを議論できるが，ここでは紙面の 都合上 $\tau_{2}=0 \mathrm{ps}$ のにに注目する。計算手法の詳細は省略す るが, Figure $8 \mathrm{~b}$ の計算においての 1 つの注意点は, 計算の 中に局所場効果が含まれていないことである（局所場効果
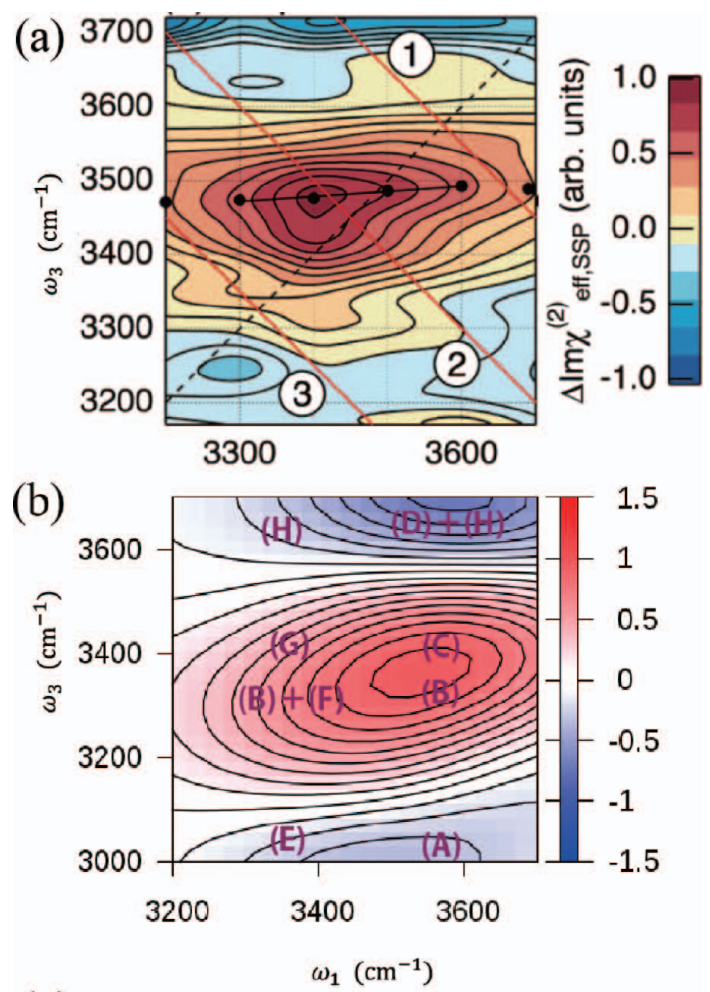

(c)

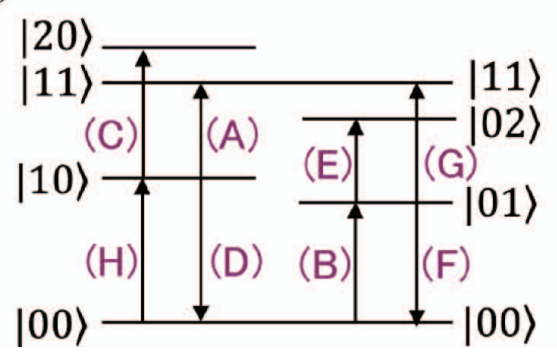

Figure 8. (a) The experimental $2 \mathrm{D}$ HD-VSFG spectra ${ }^{39}$ of the air/ water $\left(\mathrm{H}_{2} \mathrm{O}\right)$ interface at $\tau_{2}=0.0 \mathrm{ps} . \omega_{1}$ and $\omega_{3}$ correspond to the pump and the probe frequency, respectively. (b) The calculated spectrum ${ }^{47}$. (c) Energy level scheme of panel (b). This figure is reproduced from ref. 39 and 47.

を入れた $2 \mathrm{D}$ スペクトル計算は計算負荷が非常に大きい)。 Figure 2 で議論したように，この計算で用いられたモデル では水素結合領域の応答が小さく，定常状態スペクトルの 低波数側の特徵が再現されないことになる。局所場効果を 2D HD-VSFG スペクトル計算に取り入れることは今後の課 題であるが, それでもスペクトルの大まかな特徵は議論で きる。まず, 実験と計算両者に共通して, 以下の特徵が確 認できる。

(i) $\omega_{3} \sim 3,600-3,700 \mathrm{~cm}^{-1}$ に横長に青色（負）の領域

(ii) $\omega_{3} \sim 3,400-3,500 \mathrm{~cm}^{-1}$ に横長に赤色（正）の領域

（iii）赤色の領域の下に青色（負）の領域 対角に沿うブリーチバンドの振舞いに注目してみると, $\left(\omega_{1}\right.$, $\left.\omega_{3}\right) \sim\left(3,700 \mathrm{~cm}^{-1}, 3,700 \mathrm{~cm}^{-1}\right)$ の領域では, Free $\mathrm{OH}$ の振動 を $\omega_{1}$ の振動数で励起したとき, Figure 3 (a) で示された定 常状態スペクトルの正のバンドの占有数が減少するため青 色（負）を示すことになる。また, $\left(\omega_{1}, \omega_{3}\right) \sim\left(3,400 \mathrm{~cm}^{-1}\right.$, $\left.3,400 \mathrm{~cm}^{-1}\right)$ の領域では, H-bonding $\mathrm{OH}$ の振動を $\omega_{1}$ の振動 
数で励起したとき, 定常状態スペクトルの負のバンドの占 有数が減少するためその領域が赤色（正）を示すことにな る。2D スペクトルには, これらのブリーチバンドと対に なって， $\omega_{3}$ 軸に沿ってそれらとは逆符号のホットバンドが あらわれるはずである。実際, 上記（iii）の低波数側の青 色の領域は, H-bonding $\mathrm{OH}$ のブリーチバンド (赤色) に対 するホットバンドであると考えられる。しかし， 2D HDVSFG スペクトルにはFree OH のホットバンドがH-bonding $\mathrm{OH}$ のブリーチバンドと重なっていると考えられ，スペク トルの帰属がかなり複雑になる。さらに, 上記（i）のバン ドに関して注目されるべきは, $\left(\omega_{1}, \omega_{3}\right) \sim\left(3,400 \mathrm{~cm}^{-1}, 3,700\right.$ $\left.\mathrm{cm}^{-1}\right)$ の非対角部分でも有意な青色の領域がみえることであ る。2Dスペクトルでこのようなクロスピークが存在するこ とは，水素結合環境の異なる振動子間にエネルギー移動, あるいは非調和カップリングが存在することを意味する。 ここでエネルギー移動とよんでいるのは, H-bonding $\mathrm{OH}$ あ るいは Free $\mathrm{OH}$ どちらかの励起エネルギーがもう一方に伝 播していくことであり, 分子回転にともなう振動数変化の 効果 (chemical exchange) も含まれる。一方, 非調和カッ プリングとは，先に述べた $v=0 \rightarrow 1$ 間と $v=1 \rightarrow 2$ 間と のエネルギー差により生じるもので, 非調和系の $2 \mathrm{D}$ スペ クトルには典型的にみられるカップリングである。今の場 合, $\tau_{2}=0 \mathrm{ps}$ の遅延時間のスペクトルにクロスピークがあ らわれているので, エネルギー移動によるものであるとは 考えにくい。実際, 我々の MD シミュレーションでは, こ のクロスピークが非調和カップリングによるものであるこ とを示唆する結果を得た。MD シミュレーションから得ら れるスペクトルの帰属をまとめると, Figure 8（b）に示さ れる2Dスペクトルは, Figure 8 (c) のエネルギー準位図 に対応する。まず, 対角に沿う $(\mathrm{D})+(\mathrm{H})$ と $(\mathrm{B})+(\mathrm{F})$ は, Free $\mathrm{OH}$ と H-bonding $\mathrm{OH}$ のブリーチバンド, (C) と (E) にはそ れらのホットバンドが重なる。さらに, $(\mathrm{H})$ と $(\mathrm{G}),(\mathrm{B})$ と (A) にはそれらのクロスピークが振動の非調和性の結果と してあらわれる。これらのピークは, 調和振動子系では完 全に打ち消しあうものと考えられる。我々の MD シミュ レーションでは調和振動子系で全てのピークが消失するこ とを確認している。今回の MD シミュレーションでは, 2D HD-VSFG スペクトルを解釈する上で最も基礎となる非調 和カップリングの効果を明らかにした。なお，非調和カッ プリングはエネルギー移動や分子ダイナミクスとは関係な く，2D スペクトルには本来生じるべきものであることを特 記しておく。今後は,「構造」「分光」のキーワードに加え て, 界面分子の「ダイナミクス」に関する研究が広く行わ れていくことを期待したい。

\section{3. 液体界面の「輸送」の理論的アプローチ}

液体表面では, 絶えず蒸発・凝集が起こっており分子の 質量輸送が生じている。さらに, それに伴い, 蒸発・凝縮
潜熱と関係したエネルギー輸送も生じており，それらは界 面のマクロなダイナミクスに大きな影響を及ぼしている 14 界面での質量輸送を特徴付けるパラメータとして, 蒸発係 数 $\alpha_{e}$, 凝縮係数 $\alpha_{c}$ がある。これらのパラメータは, Figure 9 に示された界面での質量流束に対して以下のように定義 される。

$$
\alpha_{e}=\frac{\left\langle J^{\text {evap }}\right\rangle}{\left\langle J^{\text {out }}\right\rangle_{\mathrm{e}}} \quad \alpha_{c}=\frac{\left\langle J^{\text {cnds }}\right\rangle}{\left\langle J^{\text {coll }}\right\rangle}
$$

ここで， $J^{\text {evap }}$ は液相から蒸発する分子の質量流束， $J^{\text {out }}$ は 気相側へ向かう分子の質量流束, $J^{\mathrm{cnds}}$ は凝縮する分子の質 量流束, $J^{\text {coll }}$ は界面へ向かう気相分子の質量流束, $J^{\mathrm{ref}}$ は界 面で反射する分子の質量流束である。これらの間には, $\left\langle J^{\text {coll }}\right\rangle=\left\langle J^{\text {cnds }}\right\rangle+\left\langle J^{\text {ref }}\right\rangle,\left\langle J^{\text {out }}\right\rangle=\left\langle J^{\text {evap }}\right\rangle+\left\langle J^{\text {ref }}\right\rangle$ の関係が成り 立つ。また, 式 $(6)$ において, $\left\langle J^{\text {out }}\right\rangle_{\mathrm{e}}$ の添字 $\mathrm{e}$ は, 気液平衡 状態の量を表し, $\left\langle J^{\text {out }}\right\rangle_{\mathrm{e}}=\rho_{v} \sqrt{R T_{\ell} /(2 \pi)}, \quad\left(T_{\ell}\right.$ : 凝縮相温度, $R$ : 気体定数, $\rho_{v}$ : 凝縮相温度 $T_{\ell}$ の飽和蒸気密度 $)$ と表され る。気液平衡状態では, $\left\langle J^{\text {coll }}\right\rangle_{\mathrm{e}}=\left\langle J^{\text {out }}\right\rangle_{\mathrm{e}},\left\langle J^{\text {cnds }}\right\rangle_{\mathrm{e}}=\left\langle J^{\text {evap }}\right\rangle_{\mathrm{e}}$ の関係が成り立つため, 式 (6)から $\alpha_{e}=\alpha_{c}(\equiv \alpha)$ となる。液 体界面での物質，エネルギー輸送を記述するためには， $\alpha$ を求めるだけでは不十分であり, 界面から出てくる分子 $\left(\left\langle J^{\text {out }}\right\rangle\right)$ に対する速度分布関数 $f^{\text {out }}$ を知る必要がある $\left(f^{\text {out }}\right.$ は気相領域の輸送を支配する Boltzmann 方程式の気液界面 での境界条件になる。詳しくは文献 48,49 等を参照のこと)。 $\mathrm{MD}$ シミュレーションでは $\alpha$ を含め $f^{\text {out }}$ を直接評価でき る50,51。Figure 10 に計算で求めたアルゴン，水，メタノー ルの気液界面での $\alpha$ の值を示す。ここで，横軸にはそれぞ れの物質の臨界温度で無次元化された温度をとっている。 結果から， $\alpha$ は低温で 1 に近づくこと，臨界温度に近づく と 0 に近づくこと,さらに無次元温度の目盛りでは $\alpha$ は物 質によって大きく異ならないことがわかる。次に，MD シ ミュレーションで計算した $f^{\text {out }}$ の結果を議論する。今まで 広く用いられてきた境界条件 $f^{\text {out }}$ は，気相の状態にかかわ らず液相温度 $T_{\ell}$ の Maxwell-Boltzmann 分布になることが仮 定されてきた（完全適応型境界条件 49 という）。しかし, 我々の MD シミュレーション結果から, 気相が非平衡状態 になると界面垂直方向に対しては完全適応型, 界面平行方 向に対して不完全適応型の速度分布関数を示すことが明ら かとなった ${ }^{52}$ 。「不完全適応」とは, 気相分子が界面に衝突 後，界面の温度に十分緩和することなく反射されることを

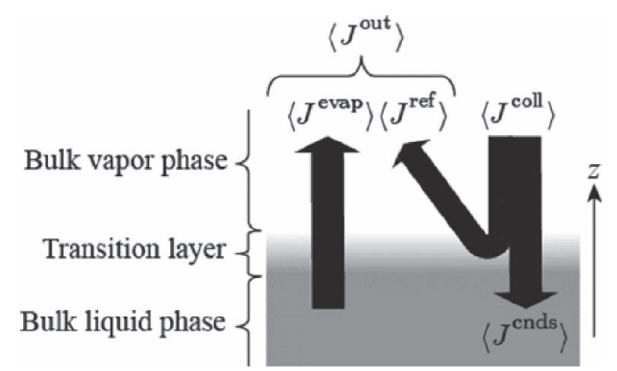

Figure 9. Definitions of molecular fluxes $J$ at a vapor/liquid interface. 


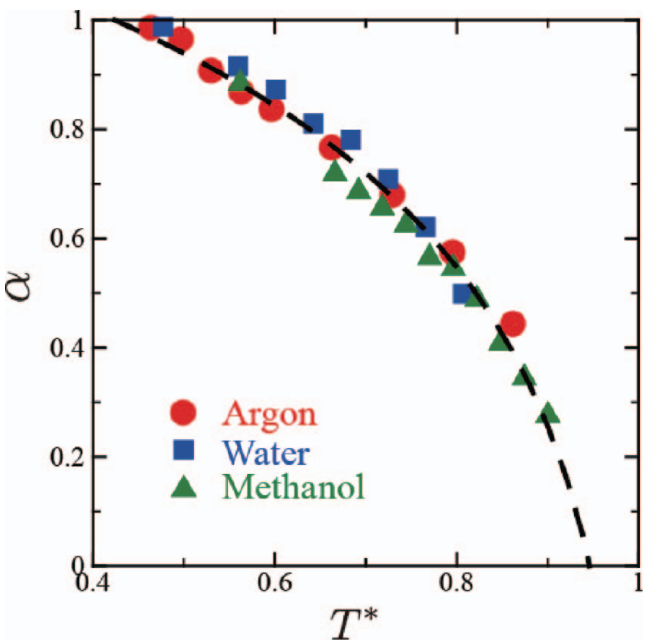

Figure 10. MD simulation result of the parameter $\alpha$ of argon, water, and methanol, as a function of the reduced temperature devided by their critical temperatures. This figure is reproduced from ref. 16.

意味している。更なる解析から, 気相分子が界面に衝突す る際に分子速度の緩和の時定数が方向によって異なること が異方的境界条件の原因であることがわかり，この効果が 界面でのエネルギー輸送に影響を与えることを明らかにし た ${ }^{16}$ 。また, 反射分子の緩和を特徵付ける温度適応係数 $\alpha_{t}$ を MD シミュレーションで直接計算することに成功し, Boltzmann 方程式の気液界面での境界条件を理論的に求め るための方法論を確立した。今後は，様々な物質，あるい は混合溶液表面での $\alpha, \alpha_{t}, f^{\text {out }}$ を計算し, 境界条件を確立 していくと共に，それを Boltzmann 方程式，流体力学理論 とカップルさせることにより気泡力学の問題に適応してい く予定である。

本稿で紹介した研究を遂行するにあたり，「構造」「分光」の研 究は東北大学理学研究科の森田明弘教授に,「輸送」の研究は北海 道大学名誉教授の藤川重雄先生にお世話になりました。また, 2D HD-VSFG 研究に関しては, 理化学研究所の田原太平主任研究員, 埼玉大学工学部の山口祥一教授, 理化学研究所の二本柳聡史博士, 井上賢一博士らによる実験サイドからのご意見，ご議論を頂き発 展しました。ここに謝意を表したいと思います。

\section{参考文献}

(1) Seinfeld, J. H.; Pandis, S. N. In Atmospheric Chemistry and Physics; Wiley: New York, 1998.

(2) Jungwirth, P.; Finlayson-Pitts, B. J.; Tobias, D. J. Chem. Rev. 2006, 106, 1137-1139.

(3) Knipping, E. M.; Lakin, M. J.; Foster, K. L.; Jungwirth, P.; Tobias, D. J.; Gerber, R. B.; Dabdub, D.; Finlayson-Pitts, B. J. Science 2000, 288, 301-306

(4) Garrett, B. C.; Schenter, G. K.; Morita, A. Chem. Rev. 2006, 106, $1355-1374$

(5) Winter, B.; Faubel, M. Chem. Rev. 2006, 106, 1176-1211.

(6) Shen, Y. R. In Proceedings of International School of Physics “Enrico Fermi”; North Holland: Amsterdam, 1994; Vol. CXX, pp
$139-165$.

(7) Shen, Y. R.; Ostroverkhov, V. Chem. Rev. 2006, 106, 1140-1154.

(8) Richmond, G. L. Chem. Rev. 2002, 102, 2693-2724.

(9) Gopalakrishnan, S.; Liu, D.; Allen, H. C.; Kuo, M.; Shultz, M. J. Chem. Rev. 2006, 106, 1155-1175.

(10) Morita, A.; Ishiyama, T. Phys. Chem. Chem. Phys. 2008, 10, 5801-5816.

(11) Ishiyama, T.; Imamura, T.; Morita, A. Chem. Rev. 2014, 114, 8447-8470.

(12) Lauterborn, W.; Kurz, T. Rep. Prog. Phys. 2010, 73, 106501.

(13) Brennen, C. E. In Cavitation and Bubble Dynamics; Oxford University Press: Oxford, 1995.

(14) Fujikawa, S.; Yano, T.; Watanabe, M. In Vapor-Liquid Interfaces, Bubbles and Droplets; Springer-Verlag: Heidelberg, 2011.

(15) Marek, R.; Straub, J. Int. J. Heat Mass Transfer 2001, 44, 39-53.

(16) Ishiyama, T.; Fujikawa, S.; Kurz, T.; Lauterborn, W. Phys. Rev. E Stat. Nonlin. Soft Matter Phys. 2013, 88, 042406.

(17) McQuarrie, D. A. In Statistical Mechanics; Harper Collins Publishers: New York, 1976.

（18）二本柳聡史，Molecular Science 2013, 7, A0060.

(19) Morita, A.; Hynes, J. T. J. Phys. Chem. B 2002, 106, 673-685.

(20) Badyai, Y. S.; Saboungi, M. L.; Price, D. L.; Shastri, S. D.; Haeffner, D. R.; Soper, A. K. J. Chem. Phys. 2000, 112, 9206.

(21) Böttcher, C. J. F. In Theory of Electric Polarization; Elsevier Scientific Publishing Company: New York, 1973.

(22) Ishiyama, T.; Morita, A. J. Phys. Chem. C 2007, 111, 721-737.

(23) Mukamel, S. In Principles of Nonlinear Optical Spectroscopy; Oxford University Press: Oxford, 1995.

(24) Nihonyanagi, S.; Ishiyama, T.; Lee, T. K.; Yamaguchi, S.; Bonn, M.; Morita, A.; Tahara, T. J. Am. Chem. Soc. 2011, 133, 1687516880.

(25) Ji, N.; Ostroverkhov, V.; Tian, C. S.; Shen, Y. R. Phys. Rev. Lett. 2008, 100, 096102.

(26) Ishiyama, T.; Morita, A. J. Phys. Chem. C 2009, 113, 1629916302.

(27) Ishiyama, T.; Morita, A. J. Chem. Phys. 2009, 131, 244714.

(28) Ishiyama, T.; Takahashi, H.; Morita, A. Phys. Rev. B 2012, 86, 035408.

(29) Kirkwood, J. G.; Buff, F. P. J. Chem. Phys. 1949, 17, 338.

(30) Chen, X.; Hua, W.; Huang, Z.; Allen, H. C. J. Am. Chem. Soc. 2010, 132, 11336-11342

(31) Hsieh, C. S.; Okuno, M.; Hunger, J.; Backus, E. H.; Nagata, Y.; Bonn, M. Angew. Chem. Int. Ed. 2014, 53, 8146-8149.

(32) Hu, D.; Chou, K. C. J. Am. Chem. Soc. 2014, 136, 15114 15117.

(33) Ishiyama, T.; Takahashi, H.; Morita, A. J. Phys. Chem. Lett. 2012 3, 3001-3006.

(34) Ishiyama, T.; Morita, A. J. Chem. Phys. 2014, 141, 18 C503.

(35) Wei, X.; Miranda, P. B.; Shen, Y. R. Phys. Rev. Lett. 2001, 86, $1554-1557$.

(36) Wei, X.; Miranda, P.; Zhang, C.; Shen, Y. Phys. Rev. B 2002, 66, 85401.

(37) Ishiyama, T.; Takahashi, H.; Morita, A. J. Phys. Condens. Matter 2012, 24, 124107.

(38) Nihonyanagi, S.; Singh, P. C.; Yamaguchi, S.; Tahara, T. Bull. 
Chem. Soc. Jpn. 2012, 85, 758-760.

(39) Singh, P. C.; Nihonyanagi, S.; Yamaguchi, S.; Tahara, T. J. Chem. Phys. 2012, 137, 094706.

(40) Eftekhari-Bafrooei, A.; Borguet, E. J. Am. Chem. Soc. 2010, 132, 3756-3761.

(41) Hsieh, C.-S.; Campen, R.; Vila Verde, A.; Bolhuis, P.; Nienhuys, H.-K.; Bonn, M. Phys. Rev. Lett. 2011, 107, 116102.

(42) Zhang, Z.; Piatkowski, L.; Bakker, H. J.; Bonn, M. Nature Chemistry 2011, 3, 888-893.

(43) Hsieh, C. S.; Campen, R. K.; Okuno, M.; Backus, E. H.; Nagata, Y.; Bonn, M. Proc. Natl. Acad. Sci. USA 2013, 110, 1878018785.

(44) Fayer, M., In Watching Ultrafast MolecularMotions with $2 D I R$ Chemical Exchange Spectroscopy; World Scientific Publishing: Singapore, 2011.

(45) Fayer, M., Ed. In Ultrafast Infrared Vibrational Spectroscopy;
CRC Press: Boca Raton, 2013.

(46) Singh, P. C.; Nihonyanagi, S.; Yamaguchi, S.; Tahara, T. J. Chem. Phys. 2013, 139, 161101.

(47) Ishiyama, T.; Morita, A.; Tahara, T. J. Chem. Phys. 2015, 142, 212407.

(48) Cercignani, C. In Rarefied Gas Dynamics; Cambridge University Press: New York, 2000.

(49) Sone, Y. In Molecular Gas Dynamics; Birkhauser: Boston, 2007.

(50) Ishiyama, T.; Yano, T.; Fujikawa, S. Physics of Fluids 2004, 16, 2899.

(51) Ishiyama, T.; Yano, T.; Fujikawa, S. Physics of Fluids 2004, 16, 4713.

(52) Ishiyama, T.; Yano, T.; Fujikawa, S. Phys. Rev. Lett. 2005, 95, 084504.

（受理日 2015 年 6 月 16 日）

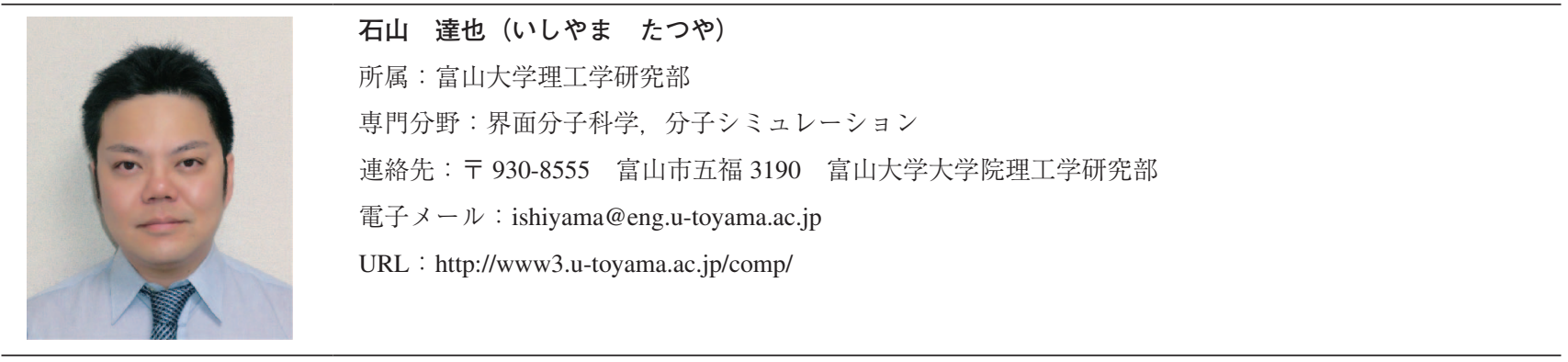

